УДК 371.3(378)

Богунов Сергій, кандидат технічних наук, Національний університет оборони України імені Івана Черняховського, м. Київ,

ORCID ID 0000-0002-4946-1604

Вітер Дмитро, доктор філософських наук, старший науковий співробітник, Національний університет оборони України імені Івана Черняховського, м. Київ,

ORCID ID 0000-0002-7330-1280

Мітягін Олег, кандидат історичних наук, Національний університет оборони України імені Івана Черняховського, м. Київ,

ORCID ID 0000-0003-1941-3561

DOI: $10.33099 / 2617-1775 / 2019-02 / 16-23$

\title{
СИСТЕМА ВІЙСЬКОВОЇ ОСВІТИ І ПІДГОТОВКИ У КРАЇНАХ- ЧЛЕНАХ НАТО (ЛИТВА, ЛАТВІЯ, ЕСТОНІЯ)
}

Досліджено систему підготовки військових фахівців, офічерських кадрів різних ступенів та ланок військового управління у краӥнах-членах НАТО (колишніх членів організації Варшавського договору). Наведено загальну структуру підготовки офіцерських кадрів збройних сил Литви, Латвї та Естонії. Показано принципи відбору, зміст навчального процесу, підвищення кваліфікації офіцерських кадрів у системі військової освіти ицх краӥн. Доведено необхідність та можливість використання досвіду краӥн-членів НАТО у сфері підготовки офічерських кадрів задля потреб реформування системи військової освіти України з метою імплементаиії відповідних стандартів НАТО.

Ключові слова: військова освіта; підготовка військових фахівців; НАТО; офічерські кадри; система; навчальний прочес

Постановка проблеми. Україна зрозуміла необхідність докорінних змін у системі національної безпеки і оборони, поставши перед загрозою втрати територіальної цілісності держави та військовою агресією, й визначивши освіту як стратегічний ресурс, у тому числі, у сфері забезпечення національних інтересів, зміцнення міжнародного авторитету та іміджу держави.

Важливою складовою освіти України є система військової освіти, що спрямована на ефективну підготовку офіцерських кадрів для Збройних Сил, які перебувають у стані активного реформування. Реформа вимагає якісних змін, підтримки курсу на євроатлантичну інтеграцію та імплементації стандартів НАТО у систему підготовки особового складу Збройних Сил України. Про ефективність такого підходу свідчить досвід країн - колишніх членів Варшавського договору (Естонія, Латвія, Литва), для яких вища військова освіта є одним із пріоритетних факторів розвитку систем національної безпеки та оборони. Ці країни пройшли складний шлях імплементації базових стандартів НАТО для розвитку національних збройних сил, в стислі терміни перейшли від радянської моделі до стандартів НАТО в системі підготовки 
військових фахівців та демонструють високій рівень вишколу та боєздатності національних збройних сил. Враховуючи, те що Україна теж входила в організацію Варшавського договору, досвід колишніх iii членів сприятиме зміцненню обороноздатності держави на шляху євроатлантичної інтеграції.

Метою статі є аналіз досвіду та визначення основних засад і принципів системи військової освіти та підготовки військових фахівців у країнах-членах НАТО (Литва, Латвія, Естонія).

Методи дослідження. У статті використано систему загальнонаукових i спеціальних методів теоретичного та емпіричного дослідження (аналіз наукової літератури з досліджуваної проблеми, систематизація та узагальнення, логічнопорівняльний методи, системний підхід, контент-аналіз).

Виклад основного матеріалу. У Литві підготовка осіб на посади офіцерського складу тактичного рівня для ЗС здійснюється у Військовій академії імені генерала Йонаса Жемайтіса (далі - ЛВА) [6]. Майбутні офіцери проходять підготовку в галузі військової освіти в поєднанні 3 університетськими навчальними програмами. Навчання у ЛВА складається 3 двох навчальних програм: програми університетського навчання та базової програми підготовки офіцерів (L1). Залежно від майбутньої посади офіцери, при необхідності, проходять також відповідні курси спеціалізації. Термін навчання становить 4 роки, 3 яких 3,5 роки відводиться на бакалаврську та військову підготовку й 0,5 роки на військову підготовку. Випускникам військової академії видається диплом бакалавра у відповідній галузі знань.

Другий (тактичний) рівень підготовки офіцерів (L2) має на меті продовження професійного розвитку офіцера й удосконалення його особистих здібностей, отриманні додаткових знань і навичок, необхідних для виконання обов'язків на відповідних посадах молодших офіцерів у штабі батальйону або підрозділі рівному військовій частині, а після проходження додаткової підготовки - для виконання обов’язків старших офіцерів під час планування i проведення спільних бойових дій (операцій) [5]. На другому (тактичному) рівні підготовки офіцери направляються на командно-штабні курси молодших офіцерів, а також на спеціальні, кваліфікаційні та інші курси в залежності від потреб литовських збройних сил і можливостей кар'єрного росту офіцер.

Підготовка офіцерів сухопутних військ тактичного рівня складається 3 двох етапів: курс підготовки молодших офіцерів (L2A); курс підготовки старших офіцерів (L2B) [6]. Метою курсу L2A у ЛBA є підготовка посадових осіб, здатних виконувати обов'язки молодших офіцерів у штабі батальйону або еквівалентному йому військовому підрозділі. Також за потреби литовських збройних сил i фінансових можливостей частина офіцерів, відібраних за конкурсом, проходить підготовку в іноземних військових навчальних закладах. Метою курсу L2B є підготовка у ЛBA посадових осіб штабів сухопутних військ, здатних грамотно планувати бойові дії і керувати ними (окремими операціями) та вирішувати інші завдання.

Підготовка офіцерів оперативного рівня управління L3 у ЛBA або закордонних ВВН3 (у першу чергу, в Балтійському оборонному коледжі (м. 
Тарту, Естонія) здійснюється шляхом курсової підготовки [9]. Підготовка осіб офіцерського складу оперативного рівня на посади, що належать до переліку загальних військових посад сухопутних військ, здійснюється на командноштабних курсах підготовки офіцерів оперативного рівня (L3). До цих курсів відноситься курс офіцерів Витаутаса Магнуса, що проводяться у ЛВА. Метою курсу є підготовка кваліфікованих офіцерів ЗС Литви, які здатні виконувати функції офіцерів сухопутних військ на рівні штабів національних i міжнародних батальйонів (бригад). Курси тривають 19 тижнів та на теперішній час $є$ єдиними фаховими курсами 3 підготовки старших офіцерів сухопутних військ в країнах Балтії.

Підготовка осіб офіцерського складу стратегічного рівня L4 на посади, що належать до переліку загальних військових посад, здійснюється заочно на стратегічному курсі у Балтійському військовому коледжі або у ЛВА шляхом навчання за акредитованими магістерськими програмами за наступними спеціальностями: "Національна безпека та оборона" (забезпечує отримання кваліфікації “магістр національної безпеки”); “Військова дипломатія” та "Управління персоналом". Термін навчання становить 2 роки [9].

Підготовка офіцерських кадрів для сил оборони Естонії, Національної ліги оборони, інших військових організацій та установ здійснюється у Вищій військовій школі Об'єднаних навчальних закладів сил оборони - Естонському національному коледжі оборони (м. Тарту) та складається 3 декількох [7; 8; 9]. Базовий навчальний офіцерський курс (перший рівень) 3 терміном навчання 3 роки, на якому курсанти здобувають знання і практичні навички, необхідні командиру взводу та роти, отримують військове звання молодшого лейтенанта, здобуваючи ступінь вищої освіти “бакалавр”.

На наступному навчальному офіцерському курсі (другий рівень) 3 терміном навчання у 2 роки офіцери отримують знання і навички командирів батальйону та бригади, здобуваючи на базі Балтійського військового коледжу вищу освіту за ступенем "магістр".

Після закінчення коледжу у випускників є можливість навчатися ще на двох курсах [4]:

- старший (оперативний) навчальний офіцерський курс (третій рівень) 3 терміном навчання 1 рік в Балтійському військовому коледжі;

- вищий (стратегічний) навчальний офіцерський курс (четвертий рівень) 3 терміном навчання у кілька місяців у Балтійському військовому коледжі або за кордоном на вищих офіцерських курсах.

Підготовка осіб на посади офіцерського складу тактичного рівня для ЗС Латвії здійснюється у Національної академії оборони Латвії (НАОЛ) і включає: базову підготовку офіцерів (L1); кар'єрні курси офіцерів (тактичний (L2), операційний (L3) i стратегічний (L4) рівні); курси за спеціальністю; кваліфікаційні та інші курси [3].

Базова військова освіта в латвійських військових навчальних закладах отримується на основі вищої університетської освіти (ступінь бакалавра) 3 обов’язковим навчанням на курсах професійної підготовки за відповідними 
спеціалізаціями 3 однієї загальної військової спеціальності. Цивільна університетська освіта (ступінь бакалавра) і відповідний військовий навчальний курс для підготовки офіцерів за інженерними та гуманітарними спеціальностями дає їм право бути призначеними на первинні офіцерські посади.

НАОЛ надає можливість навчатися за однією з визначених чотирьох вищих професійних навчальних програм. Вступники, які мають середню освіту можуть навчатися за професійними бакалаврськими програмами з підготовки офіцерів для сухопутних військ загальною тривалістю навчання в академії 4 роки і 6 місяців. Програма професійного навчання "Командир" (з терміном навчання 1 рік і 3 місяці) пропонується особам, які мають вищу професійну освіту на академічному або другому рівні навчання 3 метою отримання вищої професійної освіти другого рівня. Перед початком навчання в академії всі відібрані кандидати на навчання повинні пройти програму первинної професійної військової підготовки: 13-тижневий курс у піхотній школі (м. Алуксне) та 8-тижневий курс у сержантської школі (м. Цесіс). Навчальна програма професійного навчання "Командир" передбачає додатковий 7тижневий навчальний курс у сержантської школі.

Крім зазначених навчальних програм професійної підготовки, НАОЛ проводить базовий курс підготовки офіцерів для спеціалістів тривалістю 10 тижнів, на який залучаються випускники вищих навчальних закладів (лікарі, юристи, теологи, диригенти, психологи тощо) 3 метою підготовки військових фахівців, які виконуватимуть обов'язки в підрозділах національних збройних сил на посадах офіцерів відповідно до отриманих ними цивільних спеціальностей.

Підготовка осіб на посади офіцерського складу оперативного рівня для ЗС Латвії здійснюється протягом 1,5 роки на очній формі навчання у НАОЛ та закордонних військових навчальних закладах (у першу чергу, у Балтійському військовому коледжі) в рамках акредитованої в НАОЛ магістерської програми "Військове управління та безпека" [1; 9].

Підготовка осіб на посади офіцерського складу стратегічного рівня для ЗС Латвії здійснюється у закордонних військових навчальних закладах (Балтійський військовий коледж).

3 метою підвищення рівня підготовки офіцера перед його призначенням на нову посаду, яка вимагає збільшення обсягу знань і навичок, передбачено навчання на відповідних курсах. Кар'єрні курси є обов'язковою умовою для зайняття офіцером більш високих посад. Крім цього існують спеціалізовані курси та курси підвищення кваліфікації, які передбачають отримання офіцером військової спеціальності або кваліфікації [2].

Спільними рисами та основними вимогами для систем військової освіти Литви, Латвії, Естонії є:

- забезпечення узгодженості державних стандартів освіти згідно 3 Національною рамкою кваліфікацій та вимог стандартів НАТО у підготовці військових фахівців; 
- підвищення якості та ефективності підготовки кадрів для сектора безпеки та оборони за рахунок використання нових технологій і інтерактивних методів навчання;

- підвищення конкурентоспроможності військових навчальних закладів за рахунок удосконалення освітнього процесу та скорочення строків навчання;

- забезпечення високого рівня професійної компетентності випускників військових навчальних закладів;

- підвищення вимог до підготовки викладачів як у теоретичному, так і в практичному аспектах, навчання їх іноземним мовам;

- спроможність здійснювати мобільність викладачів та тих, хто навчається, у рамках військових університетів, коледжів та шкіл країн НАТО.

Висновки та перспективи подальших наукових розвідок. Фактично, сьогодні стратегічні пріоритети освітньої політики сектору безпеки та оборони країн, що входили до складу колишньої організації Варшавського договору, а наразі $\epsilon$ країнами-членами НАТО (зокрема Естонії, Латвії, Литви), передбачають здійснення Україною на шляху євроатлантичної інтеграції у межах системи підготовки офіцерських кадрів для ЗС низки важливих заходів. Серед них слід акцентувати увагу на запровадженні дієвої системи стратегічного управління освітніми процесами в секторі безпеки та оборони, що спрямована на раціональне використання наявного кадрового потенціалу, а також вжиття системних заходів щодо його відтворення в інтересах захисту національної безпеки кожної держави. Іншою важливою умовою підвищення ефективності системи підготовки офіцерських кадрів $\epsilon$ встановлення уніфікованих стандартів та процедур для освітньої політики в секторі безпеки та оборони, в інтересах забезпечення потреб національної безпеки. Ці стратегічні орієнтири потребують реалізації конкретних напрямів реформування системи підготовки офіцерських кадрів шляхом створення сприятливих умов для реалізації офіцерами інтелектуального потенціалу та професійної майстерності в умовах проходження військової служби.

Як свідчить досвід країн-членів НАТО, для України існує необхідність професіоналізації освітньої політики шляхом модернізації системи базового і професійного навчання. При цьому трансформація систем підготовки військових фахівців Литви, Латвії та Естонії базується на впровадженні інноваційних підходів до систем національної безпеки та оборони держав, розвитку їх збройних сил, нових вимог до підготовки військових кадрів, сучасних моделях підготовки військових фахівців, прийнятих у країнах-членах HATO.

Національна система військової освіти потребує перегляду концептуальних засад підготовки офіцерських кадрів тактичного, оперативного та стратегічного рівнів на основі імплементації ключових елементів відповідних концепцій країн-членів НАТО. Зокрема, йдеться про максимальне збереження національної системи військової освіти з урахуванням сучасних моделей підготовки військових фахівців, прийнятих у країнах-членах НАТО, яка вимагає забезпечення єдності і взаємодоповнення із системою цивільної 
освіти, поряд із урахуванням необхідності навчання цивільних осіб з питань національної безпеки та оборони у зв'язку з суспільною потребою відповідно до нових викликів та загроз безпеці країн.

У свою чергу варто зазначити, що у підготовці кадрів забезпечення безпеки i оборони у країнах-членах НАТО на перший план висувається практичне спрямування навчання, що зорієнтовано на вирішення конкретних практичних завдань. При підготовці кадрів для сфери національної безпеки та оборони багато уваги приділено вивченню іноземних мов та інших важливих для безпеки держави предметів в області міжнародних відносин. 3 урахуванням цього варто звернути увагу на необхідність переорієнтації системи підготовки офіцерських кадрів в Україні на спеціалізацію, інтенсивність та короткостроковість навчального процесу.

\section{ЛIТЕРАТУРА}

1. Militara dienestra likmus. - [Електронний ресурс]. - Режим доступу: https://likumi.lv.

2. Apstitrinata ar aizsardzibas ministra gada 06.11.2012 paveli № 185. - [Електронний pecypc]. - Режим доступу: http://www.mob.gov.lv.

3. Latvijas Nacionala aizsardzibas akademija. - [Електронний ресурс]. - Режим доступу: http://www.naa.mil.lv.

4. Nutarimas del generolo jono zemaicio lietuvos karo akademijos statuto patvirtinimo. [Електронний ресурс]. - Режим доступу: https://e-seimas.lrs.lt.

5. Guidelines of the Minister of National Defence. - [Електронний ресурс]. - Режим доступу: https://kam.lt.

6. Generolo Jono Zemaicio Lietuvos karo akademija. - [Електронний ресурс]. - Режим доступу: https://lka.lt.

7. Estonian National Defence College. - [Електронний ресурс]. - Режим доступу: https:// www.ksk.edu.ee.

8. Officers' School of the Estonian National Defence College. - [Електронний ресурс]. Режим доступу: https:// www.sojakool.ee.

9. Baltic Defence College. - [Електронний pecypc]. - Режим доступу: https:// www.baltdefcol.org.

\section{REFERENCES}

1. Militara dienestra likmus. - Available at: https://likumi.lv., (in Latvian).

2. Apstitrinata ar aizsardzibas ministra gada 06.11.2012 paveli № 185. - Available at: http://www.mob.gov.lv., (in Latvian). Latvian).

3. Latvijas Nacionala aizsardzibas akademija. - Available at: http://www.naa.mil.lv., (in

4. Nutarimas del generolo jono zemaicio lietuvos karo akademijos statuto patvirtinimo. Available at: https://e-seimas.lrs.lt.

5. Guidelines of the Minister of National Defence. - Available at: https://kam.lt.

6. Generolo Jono Zemaicio Lietuvos karo akademija. - Available at: https://lka.lt.

7. Estonian National Defence College. - Available at: www.ksk.edu.ee.

8. Officers' Schoo; of the Estonian National Defence College. - Available at: www.sojakool.ee.

9. Baltic Defence College. - Available at: www.baltdefcol.org. 


\section{PЕЗЮМЕ}

Богунов Сергей, кандидат технических наук Национальный университет оборони Украины имени Ивана Черняховского, г. Киев

Витер Дмитрий, доктор философских наук, старший научный сотрудник Национальный университет оборони Украины имени Ивана Черняховского, г. Київ

Митягин Олег, кандидат исторических наук Национальный университет оборони Украины имени Ивана Черняховского, г. Київ

\section{Система военного образования и подготовки в странах-членах НАТО}

\section{(Литва, Латвия, Эстония)}

Исследовано систему подготовки военных спещиалистов, офищерских кадров различных ступеней и уровней военного управления в странах-членах НАТО (бывших участниц организачии Варшавского договора). Приведено общую структуру подготовки офицерских кадров вооруженных сил Литвы, Латвии и Эстонии. Показано принципь отбора, содержание учебного прочесса, повышения квалификации офицерских кадров в системе военного образования этих стран. Доказана необходимость и возможность использования опыта стран-членов НАТО в сфере подготовки офичерских кадров в прочессе реформирования системы военного образования Украинь с иелью имплементации соответствуюших стандартов НАТО.

Ключевые слова: военное образование; подготовка военных специалистов; НАТО; офищерские кадры; система; учебный процесс.

\section{SUMMARY}

Serhii Bohunov, $\mathrm{PhD}$ (technical sciences)

National Defense University of Ukraine named after Ivan Cherniakhovskyi, c. Kyiv Dmitry Viter, Dr. (Philosophical sciences), senior researcher

National Defense University of Ukraine named after Ivan Cherniakhovskyi, c. Kyiv

Oleh Mitiagin,

$\mathrm{PhD}$ (historical sciences)

National Defense University of Ukraine named after Ivan Cherniakhovskyi, c. Kyiv

\section{System of the military education and training for NATO state-members}

(Lithuania, Latvia, Estonia)

Introduction. Today is very important to deepen and develop scientific maintenance of military education in Ukraine, generalization, systematization, comprehension and integration of positive experience of military education formation and development, NATO officers' training within educational process.

Purpose. Analyze the experience of military specialists' education and training within the NATO state-members (Lithuania, Latvia, Estonia). 
Methods. The system of general scientific and special methods of theoretical and empirical research (analysis of scientific literature, systematization and generalization of materials, logic and comparative, content analysis) was used in order to realize the article purpose.

Results. The article deals with educational system and training of military specialists in different educational and military command level. A general structure of Lithuania, Latvia, Estonia Armed Forces officers training provides. It is show the principles of selection, the educational process content, the training of officers and military specialists in the system of military education in Lithuania, Latvia and Estonia.

Originality. Education and training of military specialists in the Lithuania, Latvia and Estonia Armed Forces is considered as an integral and level-based system, which is compatible with system of NATO officers' training. Experience of formation and functioning of officers' training in different military educational establishment of this states, and their theoretical and practical training can be practical for military education system of Ukraine.

Conclusion. The transformation of military specialists training system in Lithuania, Latvia and Estonia is base on innovative approaches implementation to national secure and defense system, of it armed forces development, new requirements for military specialists training, contemporary models of military specialists training, which in the NATO state-members accepted.

Key words: educational process; military education; military specialists; military training; NATO; system. 